\title{
Ulrich Möller and Matthew McCaffrey* Entrepreneurship and Firm Strategy: Integrating Resources, Capabilities, and Judgment through an Austrian Framework
}

\author{
https://doi.org/10.1515/erj-2020-0519 \\ Received November 17, 2020; accepted May 11, 2021
}

\begin{abstract}
Despite numerous calls for integrating entrepreneurship research and firm theory, there has been relatively little work done in this direction. Likewise, despite many discussions, controversy continues to surround core theoretical frameworks in strategic management such as the resource-based view and capabilities theory. This paper uses insights from early research in Austrian economics to resolve both issues. We focus on Viktor Mataja, whose work provides an original, integrated framework for understanding the relationship between entrepreneurs and firms using the judgment-based approach to entrepreneurship, strategic use of resources in the firm, and dynamic capabilities. We show how this view answers various criticisms that have been raised against the resource- and capabilities-based views. This lays a foundation for a more thoroughgoing integration of research in entrepreneurship and strategic management.
\end{abstract}

Keywords: Austrian economics, Viktor Mataja, resource-based view, capabilities theory, entrepreneurial judgment, theory of the firm, production

\section{Introduction}

The strategic management literature is enormous, but despite significant advances, debate still persists on some of its most fundamental research questions and theoretical frameworks. The most prominent examples involve questions about the role and strategic use of resources and capabilities within the firm. We contend that one valuable way to advance these debates is to adopt a multidisciplinary perspective that combines insights from strategic management, entrepreneurship, and economics. The purpose of this article is to explore one such

\footnotetext{
*Corresponding author: Matthew McCaffrey, Alliance Manchester Business School, University of Manchester, Manchester, UK, E-mail: matthew.mccaffrey@manchester.ac.uk

Ulrich Möller, Faculty of Business Studies and Economics, University of Bremen, Bremen, Germany, E-mail: umoeller@uni-bremen.de
}

¿ Open Access. @ 2021 Ulrich Möller and Matthew McCaffrey, published by De Gruyter. (c) BY This work is licensed under the Creative Commons Attribution 4.0 International License. 
research stream that we argue is useful for contemporary strategy scholars: the work of the early "Austrian" school of economics, and particularly, the theories of entrepreneurship and the firm advanced by Viktor Mataja (1857-1934). Mataja's work offers an original, integrated perspective on entrepreneurship and firm strategy that is both distinctly Austrian and surprisingly relevant for addressing current questions in management research. Starting from the union of entrepreneur and firm, Mataja places the entrepreneur at the center of production where resources have to be procured, created, combined, and deployed in anticipation of future customer wants. Correct anticipations lead to profit, and continuous correct anticipations to competitive advantage. Building on this, Mataja provides useful concepts and ideas, like the differentiation between the original source and the modifiers of profit, and the backward imputation of value.

We explore his ideas in light of contemporary research, and show two things in particular: first, that Mataja's unique combination of entrepreneurship and capital theory takes important steps toward integrating the resource-based and capability theories with organizational economics and the judgment-based view of entrepreneurship, thereby uniting entrepreneurship theory with the theory of the firm. Second, this integration provides a framework that answers important questions about resources and capabilities, including the tautology critique, indeterminate concepts like competitive advantage, and the ad hoc nature of heterogeneity and dynamism. ${ }^{1}$

Viewed in light of contemporary research, Mataja's theories occupy the common ground between economics, entrepreneurship, and strategic management. We therefore stress at the beginning that this is not an exercise in the history of economic thought, but an investigation of important trends, questions, and debates in modern entrepreneurship and strategy research. We use Mataja's ideas as a framing device and an organizational tool to integrate and extend current thinking. Nevertheless, it is worth asking why we should take the time to apply older economic ideas to current debates. The answer is that works like Mataja's can contribute time-tested but forward-looking perspectives on management studies, especially in entrepreneurship and strategic management (see, e.g. the examples in Foss and Klein 2012; McCaffrey 2018). In fact, modern strategic management owes much to economists old and new, including many working outside the economic mainstream (Pitelis and Runde 2017). In addition, economics offers a

1 We use "theory of the firm" to cover those theories that explain the rationale, origin, and boundaries of business firms. The resource-based view of the firm argues that a business's competitive advantage is created through careful management of its internal resources (Barney 1991). Dynamic capabilities theory, on the other hand, finds the source of competitive advantage in the firm's ability to adapt capabilities in the face of change (Teece, Pisano, and Shuen 1997). 
particularly wide range of useful conceptual foundations on which to base contemporary work. To take only one example, the period after the marginalist revolution (c. 1871) but before the monopolistic competition revolution (c. 1933) has proved especially fruitful in terms of inspiring modern work. Writers of this period whose ideas have found new audiences in management include Carl Menger (Kirzner 1978), Alfred Marshall (Loasby 2007), Frank Fetter (McCaffrey 2016), Joseph Schumpeter (Baumol 1993), Frank Knight (Foss and Klein 2012), and Ludwig von Mises (Foss, Klein, and McCaffrey 2019; Salerno 2008), to name only a few. Furthermore, the German-language literature on business economics from the late 19th century, though largely overlooked in English-speaking countries for many years, has been rediscovered and applied to contemporary research as well (Olbrich, Rapp, and Follert 2020). Within this growing body of work, the ideas of the "Austrian" economists are especially prominent (e.g. Foss and Klein 2012, 2015; Jacobson 1992; Kirzner 1997; McCaffrey 2018). “Austrian” ideas have, for instance, been influential in the early foundations of resource and capability theory (Connell 2007; Locket 2005). One reason for this is that from its earliest days the Austrians emphasized the importance of analyzing economic behavior in realistic ways that are relevant for practical business activity, and that lead naturally to studying the importance of entrepreneurs, firms, and related topics. All of these are germane to management studies, making for a large number of common interests (Foss, Klein, and McCaffrey 2019).

The paper is organized as follows: Section 2 presents four core insights from Mataja's (1966) theory of entrepreneurship. Section 3 builds upon these insights and outlines an integrative framework for entrepreneurship and the theory of the firm. In Sections 4 and 5 we then apply this framework to ongoing debates over the resource-based and capability views, respectively, focusing particularly on how some of the criticisms that have been leveled against these theories can be avoided. Section 6 provides some concluding discussion.

\section{An Overview of Mataja's Theory of Entrepreneurship}

Viktor Mataja was among the first of Carl Menger's doctoral students at the University of Vienna, and he produced the first book-length treatment of entrepreneurship in the Austrian tradition, Der Unternehmergewinn: Ein Beitrag zur Lehre von der Gütervertheilung in der Volkswirthschaft ([1884] 1966), or, Entrepreneurial Profit: A Contribution to the Doctrine of Distribution of Goods in the National Economy. The book was acknowledged by his Austrian contemporaries as a 
genuine achievement. Menger listed Mataja as one of his most successful students (Hülsmann 2007: 139), and Eugen von Böhm-Bawerk described Mataja’s book as a 'creditable' piece of work (Böhm-Bawerk 1959: 458). He pointed to it particularly as an important example of how Austrian ideas could be successfully applied to the problem of entrepreneurship (Böhm-Bawerk 1962: 18). ${ }^{2}$ Despite some professional success, however, Mataja has not received the same attention as his Viennese contemporaries like Menger, Böhm-Bawerk, Schumpeter, and Mises, mainly because his works were not translated into English. As such, they were inaccessible to many English and American economists after the turn of the century, when questions about entrepreneurship and economic development received increased attention (e.g. from Schumpeter and Knight). ${ }^{3}$ Had they been translated, their original insights would likely have enjoyed greater impact in management and economics, and Mataja's place in the history of economics would be better understood. Briefly, Menger (1871) had sketched a theory of entrepreneurial action and discussed it in terms similar to those later developed by Frank Knight (1964) and Ludwig von Mises ([1949] 1998; see also Martin 1979). By exploring the entrepreneurial function within the context of Menger's theory of value and production, Mataja provides a bridge between Menger and later generations of entrepreneurship theorists, and helps show the continuity of Austrian thinking on the subject.

Mataja (1966) defines entrepreneurship and enterprise in terms of exchange: 'The distinctive feature of the enterprise is production for exchange, the distinctive feature of the entrepreneur is that this production happens on his own account'

2 Der Unternehmergewinn was also discussed by other contemporaries, though reactions were mixed. Schumpeter endorsed Mataja's conception of the entrepreneur, suggesting that it was similar to his own, as long as its dynamic element was emphasized. Yet he also claimed it was a passive theory rather than a functional one based on entrepreneurial action (Schumpeter 1983: 76). He later classified Mataja's theory along with the German writings of the period (Schumpeter 1954, p. 895). On the other hand, Friedrich von Kleinwächter (1884: 283-284), a proponent of the German Historical School, criticized Mataja-as well as most contributions to entrepreneurship-for focusing on microeconomic phenomena like values, prices, and costs, instead of taking a macroview of the entrepreneur's role in the national economy. Frank Knight also studied Mataja's work, and especially praised his historical survey of entrepreneurship theories. At the same time, however, he believed Mataja had not made sufficient progress in developing an original conceptual framework. In what follows, we argue that these more critical views are ironic, because much of Mataja's writing remains relevant for modern management studies for the same reasons Knight's work does (Knight 1964: 22, 29).

3 Mataja would also go on to write influential works on marketing (Mataja 1916) that further demonstrate the overlap between his economic theories and modern management studies, and he made significant, novel contributions at the intersection of economics and jurisprudence (Mataja 1888) that anticipated the American law and economics movement (Grechenig and Gelter 2008). 
(p. 142). He further explains that 'the entrepreneur [is] the one who receives entrepreneurial profit and no one else [is] considered an entrepreneur' (p. 139). This definition entails three major characteristics that we discuss in more detail: first, the firm is concerned with production; second, the entrepreneur must bear the costs of that production, and therefore; third, the entrepreneur receives profits or incurs losses. Each point is relevant for current research, and provides an effective way to highlight the integrative nature of Mataja's work.

Mataja also anticipated more recent theories by suggesting that entrepreneurship is not restricted to one person. Instead, it is an economic function that can be performed by a wide array of individuals or teams (McCaffrey 2018), and it generates a special kind of income. However, if entrepreneurial profit is somehow special, there must be some difference between it and the returns to labor and capital: not everyone is an entrepreneur, ${ }^{4}$ and Mataja strictly separates entrepreneurs from managers. Following Menger (1871), Mataja invokes as a necessary condition for defining entrepreneurship that it not be tradeable, and thus has no market price. Therefore, management is not entrepreneurial because it does command a market price. Despite this distinction though, Mataja clearly acknowledges that the functions of the entrepreneur and manager are often performed by the same person, even if they are conceptually distinct.

If production for exchange is the core characteristic of entrepreneurship, how does the organization of production yield a profit for the entrepreneur? Mataja's answer begins with Menger's (1871) theory of goods. Menger's theory ordered goods according to their closeness to satisfying consumer needs, starting from immediate consumption. A final product ready for consumption is a good of the first order, while all the goods used to produce this final product belong to higher orders. For example, resources used to make consumer goods are of the second order, goods and services used to produce second-order goods are of the third order, and so on, until all factors of production are accounted for, and all production is traced back to the original factors of land and labor. These ordered goods loosely correspond to production stages, e.g. a supermarket is a second-order good, a delivery truck is a third-order good, etc. Together, the orders constitute a "structure of production," a collection of scarce, heterogeneous resources located at different stages in the production of many different goods and services. This structure has two important characteristics. First, production takes time, and therefore each stage has a temporal aspect. This implies resource heterogeneity, because the same physical object, e.g. a delivery truck, can be used at different stages and therefore can belong to different orders. Furthermore, production occurs before exchange, and therefore production costs must be paid before any final

4 As implied, for example, in Kirzner's theory (1973). 
sale to consumers. Second, while production moves forward from the original factors to final consumer goods, valuation moves backward. The price the customer is willing to pay for the final product is ultimately determined by the use value they ascribe to it. The value of the higher order goods and resources used to produce the final product are derived from its use value, which is subjective for both consumers and entrepreneurs.

Following the definitions given above, Mataja locates the entrepreneur at the center of Menger's structure of production. The entrepreneur decides which resources to use and how much to pay for them. In order to do so, the contribution of a resource must be appraised. Since 'the value of goods of higher order depends on the value of the goods of lower order that is created by their combinations' (Mataja 1966: 148), and the resources need to be paid for before a sale is made, entrepreneur's valuations of resources depend on their estimates of the ability of the final product to satisfy consumer needs. This appraisal requires 'anticipative judgment [s]' about future states (Mataja 1966: 149). If entrepreneurs' estimations are correct, the price achieved for the final product exceeds the prices paid for inputs, creating entrepreneurial profit. As multiple entrepreneurs estimate the future value of a certain resource, their varying judgments determine its market value. Importantly though, combining resources per se does not create value because profit is only realized afterward: real value creation does not happen during production, only at exchange. In fact, if the entrepreneur is wrong, value may be destroyed because higher-value resources were used to produce lower-value products. An entrepreneur only receives a profit if the price paid for productive resources now is below the price customers will pay for the final product in the future. Entrepreneurial profit is the strictly (intertemporal) positive differential of revenue over costs. Costs include resources owned by the entrepreneur, e.g. his labor and the capital goods contributed to production. As a result, even though entrepreneurial wages and interest payments are part of total entrepreneurial income, they are not part of entrepreneurial profit.

Focusing on one resource rather than resource combinations allows us to look a bit deeper into this approach to entrepreneurial profit. The theory agrees that every price equilibrates supply and demand in some sense, but argues that this condition may not be satisfied by one price but by a price range. That is, there exists a 'specific scope in which the market price is constituted that meets this condition' (Mataja 1966: 150). This scope is determined by two interrelated factors: the anticipative judgments of the entrepreneurs, and the number of alternative uses of the resource. Given their different estimates about the use values of the products, entrepreneurs have different willingness to pay. This in turn depends on the number of different products that can be made with the resource. The fewer alternative uses, that is, the higher their specificity, the narrower the price range 
will be. This is an early conceptualization of what Lachmann (1978) later called the 'multiple specificity' of capital: the idea that a resource has multiple yet finite uses. The source of profit is therefore the difference between the least profitable deployment of a resource and the next most profitable one (Mataja 1966: 159). However, Mataja clearly acknowledges that multiple resources are needed in production and that these resources tend to be complementary, thereby creating resource combinations. This introduces a new level of complexity, as enterprises that produce the same final product may use different combinations of resources, allowing entrepreneurs to also generate profit by finding more complementary resources or subsidizing expensive low-value resources with high-value but cheap complementary ones. This highlights the importance of the subjective perception and imagination of the entrepreneur in discovering or creating these resources.

The function of the entrepreneur, the source of entrepreneurial profit, is the anticipation of future use value and the according deployment of resources. Mataja (1966: 159) calls this the 'specific' element of entrepreneurial profit. The function of entrepreneurial profit is to guide resource deployment so that it brings about the 'most profitable structure of productive forces' (p. 173). However, he stresses that there are other elements in profit that he terms 'random' (Mataja 1966: 160). He argues that these are distinct for two reasons: (a) they are not solely associated with entrepreneurship or enterprise, but exist for other forms of action as well, and (b) they cannot be derived from the act of bearing the costs of production for exchange. Random elements thus include bargaining power based on superior market knowledge or superior entrepreneurial traits, the more efficient combination and exploitation of resources through innovation or optimization, the possession of unique resources, and access to credit. These are not original sources of profit and do not exist without the 'specific' element mentioned above. For example, if the entrepreneur's anticipative judgment is wrong, then even a highly optimized and efficient production structure will not generate profit. Also, even if an enterprise has advantageous relationships with suppliers and buyers due to its own bargaining power, lower production costs through superior coordination, and quality control, it cannot generate a profit if there is no demand for its product. The random elements are therefore not so much additional parts of entrepreneurial profit as modifiers affecting its size.

\subsection{Mataja and the Judgment-Based Approach}

Before we discuss theory integration, we will show how Mataja's theory relates to contemporary work, especially the judgment-based approach to entrepreneurship (JBA). The idea of the entrepreneur orchestrating production is common in Austrian 
economics and receives considerable attention in the capital theories of Lachmann (1978) and Kirzner (1966), as well as in recent contributions to the theory of the firm and entrepreneurship by Foss and Klein (2012) and Bylund (2015). ${ }^{5}$ Combining resources takes center stage especially in the judgment-based approach. In this view, entrepreneurs take given facts like past prices and the state of technology, interpret them based on their own idiosyncratic knowledge and experience to create beliefs about the future, and deploy their resources accordingly (Foss and Klein 2012, 2015). Crucially, the future is not predictable: it is truly uncertain (Knight 1964). Uncertainty in this context refers to 'unknown unknowns,' that is, situations that cannot be described in terms of known probabilities; alternately, we could say that uncertainty exists when either or both of the sets of options and outcomes are perceived as open (Packard, Clark, and Klein 2017).

While Knightian uncertainty is a cornerstone of the JBA, Mataja's work provides only an early version of the concept. He explicitly states that entrepreneurs possess only incomplete knowledge of relevant market conditions, e.g. the relative profitability of different lines of business, sales channels and points of purchase (p. 169); efficient production methods, e.g. large scale (p. 161); and changes in preferences and supply and demand (p. 169). This ignorance suggests uncertainty as a general condition under which Mataja's entrepreneur operates. This view is further supported by his discussion of risk and why it should be excluded from the definition of entrepreneurship-his point is that risk is not entrepreneurial because it is already captured in prices. Mataja illustrates this using the example of champagne bottling also given by von Mangold (1855: 82) and later by Knight (1964: 213), in which a known average percentage of bottles break during production. This percentage is part of ordinary business calculations, and is simply subtracted from the average number of bottles produced during a given period. Truly entrepreneurial decisions therefore lie elsewhere, and Mataja thus employs a version of the distinction between risk and uncertainty, although it is not as clear or sophisticated as Knight's (1964). ${ }^{6}$ Moreover, he clearly considered that this future value on which the entrepreneur bases production and makes decisions about acquiring resources has to be imagined in the present. All resource values

\footnotetext{
5 Although each of the theories cited here invokes the idea of directing production, they often provide radically different accounts of that process and exactly how it relates to entrepreneurship and the firm. Bylund (2015), for example, also emphasizes stages of production, perhaps more so than Foss and Klein (2012, pp. 21, 46-47, 113), who mainly use the idea as a basis for discussing capital heterogeneity.

6 Mataja's view is sometimes inconsistent from the perspective of contemporary theories of uncertainty. For instance, while he rejects quantifiable risk-taking as an element of entrepreneurial profit, his numerical examples appear to mix cases of risk (calculable) and uncertainty (incalculable) (Mataja 1966: 163-165).
} 
are 'anticipative judgment[s] about the future state that may be achieved by allocating the goods according to their use value' (Mataja 1966: 149). Yet entrepreneurs' imaginations may ultimately be wrong, and their 'estimates about the average too high or too low' (p. 165), in which case they have to bear a loss. Judgment, imagination, and beliefs therefore play a role in his theory.

Uncertainty requires entrepreneurs to exercise judgment, a decision mode that is neither fully rational nor completely random. This concept to some extent remains a black box. Despite building their theory upon it, Foss and Klein (2012) left it for other researchers to dive into the details and only suggested that judgments are related to heuristics, creativity, and confidence in the face of uncertainty. More recently they suggested intuition or "gut feeling” (Foss and Klein 2015; Klein 2017). Others argued for empathic accuracy (McMullen 2015) or customer need diagnosis (Godley and Casson 2015) as the basis of judgment. However, these latter explanations focus on appraising customer needs and refrain from implementation issues, i.e. deploying resources. Mataja's (1966) idea of judgment is more practical. For him 'every judgment of value of a good is done by taking a certain average of its expected utility' (p. 164). He goes on to explain that judgments of resource value are formed by considering qualitatively different contributions to the end product this resource may have and taking their average as the expected value. An employee may perform high or low quality work, for example, and therefore a middle ground should be used as an estimate (p. 164). We would add that also different production structures and outcomes should be considered. Judgment then can be understood as a scenario analysis in which both especially promising and unpromising scenarios are taken into account to determine an estimate. It is important to emphasize that these scenarios are not sophisticated guesses, but subjective predictions based on objective and known facts like current prices, the given production structure and state of technology. Building on Mataja we can ground judgment therefore in a quite practical and clear form of analysis that directly relates the appraisal of customers' needs to the consideration of the production structure required to satisfy them through business cases. Lewin and Cachanosky (2019) also highlight the importance of actual calculation and provide an accounting and finance-based framework for calculating the prospects of different alternatives that supplements Mataja's approach.

The notion of judgment has some overlap with the concept of dynamic capabilities. Early contributions on dynamic capabilities focused on processes and routines that are directed at transforming an existing resource base (Eisenhardt and Martin 2000; Teece, Pisano, and Shuen 1997; Zollo and Winter 2002). The execution of dynamic capabilities is triggered by entrepreneurs or managers when there is a felt need to adapt. This definition can easily be related to entrepreneurial judgment, as entrepreneurs transform resources when their perception of the 
future changes. Teece (2007) presented a more comprehensive notion of dynamic capabilities that not only included transformation processes but also the constant search for opportunities that require such processes. This "sensing” necessarily entails the imagination of future states, while the transformation processes or "seizing" require resource deployments. It is not a surprise that recent literature in this stream highlights its proximity to entrepreneurship (Helfat and Peteraf 2014; Teece 2012). However, as we explain below, there are still important differences between entrepreneurial judgment and dynamic capabilities.

In summary, there are four major insights that we draw from Mataja's theory and use as points of departure for our integrating framework in the following section: the union of entrepreneur and firm, the entrepreneurial function at the center of the production structure, the differentiation between the source ("specific element") and modifiers ("random elements") of profit, and the anticipatory nature of entrepreneurial decision making under uncertainty.

\section{Mataja's Theory as an Integrative Framework}

Mataja's theory provides the foundations for an integrated framework that can bring together several current streams of research. There are two in particular worth discussing. First, Mataja connects the theory of the firm to entrepreneurship theory, and second, he connects organizational economics with the resourcebased view (RBV) of the firm and capability theory.

\subsection{Integrating the Theory of the Firm and Entrepreneurship Theory}

Mataja treats entrepreneurship and enterprise as a conceptual union in which one does not exist without the other. Conversely, the modern literatures on entrepreneurship and the theory of the firm developed separately, and work to integrate them more fully remains ongoing (Foss and Klein 2012). This point is made especially by resource and capabilities scholars, who suggest that entrepreneurship can provide useful ways to advance theories of the firm (Barney 2001; Helfat and Peteraf 2014; Lippman and Rumelt 2003b; Teece 2014). However, progress is slow, even though suggestions abound in both the resource-based and capabilities literatures.

Alvarez and Busenitz (2001) argued than entrepreneurship could be integrated into the RBV by dis-aggregating entrepreneurship into various resources (e.g. alertness, insight, knowledge). Similarly, Wernerfelt (1984) included entrepreneurs' 
knowledge and skills in the definition of resources. At the same time, entrepreneurship has been introduced in the capabilities literature as a specific kind of cognition (Helfat and Peteraf 2014) or skill (Teece 2012) in which the preconditions for changing capabilities are called "entrepreneurial." All of these have in common that they invoke traits associated with entrepreneurship ad hoc instead of offering a consistent theory of it. Mataja, on the other hand, treats entrepreneurship and the firm together from the start. Considerable effort in the same vein has been made by Foss and Klein (2005, 2012), who show how the classical theory of the firm (i.e. transaction cost economics, property rights theory, agency theory) can advance entrepreneurship theory, and vice versa. In their view, the firm is an 'entrepreneur plus the alienable assets she owns and controls' (Klein 2017: 149). Since judgment is about the deployment of assets it cannot be delegated without selling it. Judgment therefore is not marketable, a view that Mataja shares, and so entrepreneurs use firms to act upon their intuitions (Foss and Klein 2012).

Building on organizational economics, Bylund (2016) proposes a different view, arguing that completing entrepreneurial plans, especially plans for innovation, requires production structures with resource specialization beyond the scope of the market. Because such specialization is incompatible with the market as it stands, entrepreneurs need to provide a vehicle for fitting together this specialized structure with the whole productive structure of the market. This vehicle is the firm. This view of entrepreneur in firms is, like Mataja's, explicitly grounded in Menger's theory of the stages of production. In any case, all three of the approaches mentioned above inextricably link entrepreneurship and enterprise and thereby give support to the many calls for their integration (Barney 2001; Baumol 1968; Foss and Klein 2012; Ireland, Covin, and Kuratko 2009; Teece 2014) while offering points of departure for answering them.

\subsection{Integrating Organizational Economics, the RBV, and Capabilities}

Organizational economics (especially transaction cost economics [TCE]) and capability theory have been at odds with each other in the realm of strategic management. While early contributions to capability theory were proposed as alternative explanations to transaction costs (e.g. Demsetz 1988; Winter 1988), later ones were more complementary, yet still give capabilities explanatory superiority (Argyres et al. 2012). However, there have been recent exceptions (e.g. Nagano 2020). The main issues in this debate revolved around the underlying assumptions of TCE, especially opportunism (e.g. Conner and Prahalad 1996; Freiling, Gersch, and Goeke 2008; Kogut and Zander 1992; Williamson 1993) and its 
general explanatory power on heterogeneity in profits, the core topic of strategic management (Argyres 2011). Even Oliver Williamson argued along similar lines, first, by dismissing specific strategic concerns altogether by suggesting that strategizing is economizing on transaction costs (Williamson 1991), and second, by asking how capabilities affect governance choices (Williamson 1999). Nevertheless, there is also a literature stream that argues that the distinction and hierarchy between both theories is arbitrary and that in fact TCE is able to answer the open questions of capability theory (Argyres 2011; Argyres et al. 2012; Argyres and Zenger 2012; Langlois and Foss 1999). Argyres et al. (2012) propose two major roles for TCE or organizational economics in general: first, explaining the entrepreneurial process of combining resources and how it is facilitated by governance choices, and second, explaining how organizational design and firm boundaries affect knowledge creation and sharing.

\subsection{Resources and Governance}

Mataja (1966) discusses several classical topics in organizational economics. For example, he considers governance and incentive alignment when he argues that entrepreneurial profit should be the major part of an entrepreneur's income, making his livelihood dependent on the success of the enterprise-'profit should not just be an extra payment of secondary importance' (p. 140). Specific shareholders are therefore explicitly regarded as entrepreneurs, as has also been suggested by other proponents of ownership-based theories (e.g. Foss and Klein 2012; Knight 1964). Yet at the same time production takes center stage in Mataja's analysis of entrepreneurship and the firm. Because profit is closely related to choices about what and how to produce, his approach is also similar the resourceand capabilities-based views. One of Mataja's (1966: 161) 'random' elements of profit is the more efficient exploitation of a resource. He attributes this efficiency to skills, knowledge, and experience, as well as processes and routines. Large-scale production is one example. The value of a resource is derived from the value of the final product it produces. However, most resources are capable of producing more than one product. Mataja argues that a resource is valued by the competing judgments of entrepreneurs trying to estimate the average value it is able to create. If an enterprise is able to produce more than this average it can increase output without increasing costs, or decrease costs while keeping output constant. This logic applies to both existing and substitute resources. If a new resource is a better fit with the existing production process and resource structure it may allow a higher level of exploitation of other complementary resources and even of itself. This may justify acquiring a more expensive, e.g. higher quality, resource when 
production increases disproportionately. Moreover, this average also contains the known probabilities (risks) of production failure. If the optimal average is 10 units and the failure rate is $5 \%$, the resource is valued at 9.5 units. Introducing better processes and routines that decrease production failure lead to higher average production per resource, making production more efficient and also generating a profit. This becomes especially relevant in equilibrium, where profit is zero, but more efficient resource exploitation allows for an advantage that lasts until other enterprises also employ large-scale production or bring down their failure rates.

This reasoning is commonly associated with the concepts of operative, ordinary, or zero-order capabilities (Helfat and Winter 2011; Winter 2003). These are the ability of a firm to utilize resources to produce some kind of output (Amit and Schoemaker 1993; Helfat and Lieberman 2002; Salvato and Rerup 2011), and are composed of interconnected routines (Winter 2003) and based on knowledge and learning (Freiling, Gersch, and Goeke 2008; Zollo and Winter 2002). In this evolutionary perspective, the more efficient exploitation of resources is a capability. However, from the perspective of organizational economics it may be a source of capabilities. As Argyres et al. (2012) argue, capabilities arise either due to co-specialized investments in resources, creating unique complementarity (Teece 1986), or because an entrepreneur discovers underpriced resources by identifying co-specialization among resources that others do not, or cannot effectuate due to a lack of complementary assets. Mataja accommodates both possibilities. While the latter is clearly related to his "specific" element of entrepreneurial profit rooted in judgment about resource deployment, the former speaks to the "random" element of more efficient exploitation that adds knowledge and skills to the development and change of routines. Therefore, Mataja considers both production and exchange as parts of a chain of actions that ultimately leads to satisfying a customer need. Questions of both coordinating production and of transactions (to procure inputs and sell outputs) stand side by side in his explanation of entrepreneurial profit. Production and exchange are thus mostly complementary, as Mataja's teacher Carl Menger emphasized (Loasby 2002). By discussing both transaction-related themes (e.g. bargaining power) and production-related themes (e.g. superior coordination) as relevant determinants of entrepreneurial profit, Mataja provides an integrated approach to organization and dissolves the somewhat artificial distinction between the transaction and production research streams (Argyres et al. 2012; Langlois and Foss 1999).

\subsection{Knowledge and Bargaining Power}

One particularly well-suited example of integration is superior knowledge. Mataja (1966) argues that entrepreneurs have an advantageous position in competition 
with regard to consumers, but also to capitalists and workers (who provide factors of production). He attributes this advantage to superior knowledge of the market as well as to particular entrepreneurial traits such as a 'high business drive' (p. 161) and being 'energetic' or 'vigorous' (p. 160). Entrepreneurs' advantages allow them to exploit possible price ranges in their favor by reducing resource prices while increasing the prices of final products, thereby increasing profit. The entrepreneur therefore possesses bargaining power fueled by superior knowledge that allows him to economize on transaction costs. These relations are, however, obviously more complex than Mataja's entrepreneurs simply overpowering all other market participants. Numerous power relations exist in relation to the firm. Modern examples include venture capitalists who exercise power over start-ups in need of finance, employees with specialized skills and knowledge who can dictate contract conditions, and customers who severely affect sales with the help of social media.

Although Mataja attributes this special bargaining power based on superior knowledge and skills to entrepreneurs in general, he immediately notes that maximizing profit by exercising superior knowledge or power becomes more challenging when competitors occupy similarly advantageous positions. Furthermore, he suggests that power is relevant among entrepreneurs as well, because in order to determine the total entrepreneurial profit of all entrepreneurs one would have to consider the power relations between them. This is reminiscent of transaction costs writings concerning incomplete contracts and the hold-up problem (Grossman and Hart 1986; Williamson 1985) or knowledge asymmetries (Jensen and Meckling 1976). At the same time and going beyond Mataja's argument, superior knowledge on the demand side can also exhibit positive effects by making entrepreneurial beliefs more accurate. Because valuation goes "backwards," entrepreneurs that produce goods of lower order may be better at anticipating customer valuations and therefore may be more successful in estimating resource values. Similar reasoning can be found in Barney (1986) in his seminal work on strategic factor markets, where he argues that demand-side firms have a knowledge advantage over supply-side firms with regard to resource values, which allows them to acquire resources below their net present value (Foss and Ishikawa 2007: 753). Barney neglects the customer side, however; his reasoning implies that demand-side firms are generally more profitable because of superior estimations of resource value, which is not necessarily the case. Superior knowledge of the entrepreneur therefore acts on both the specific and the random elements of profit. In the former it is related to strategy, while in the latter it is related to economizing.

Another example is the firm's boundaries. These have been of particular interest in the discussions of organizational economics and capability theory (Argyres and Zenger 2012). While TCE states that boundary decisions depend on the vulnerability of transactions to opportunism (Williamson 1985), capability 
approaches argue that firms internalize activities for which they possess a superior capability (Demsetz 1988; Kogut and Zander 1992). Argyres and Zenger (2012) synthesize both arguments and argue that firms integrate resources with unique complementarity, i.e. complementary resources that are not possessed by others, because failing to do so creates significant opportunities for hold-ups. For Mataja, every production process for exchange is an enterprise leading to broad firm boundaries, as suggested also in research on networks and strategic partnerships (Holmström and Roberts 1998). However, Mataja does not have in mind fully vertically-integrated firms controlling the whole production process of one good-he also considers suppliers of intermediate goods and the role of entrepreneurs' bargaining power. Firm boundaries in his theory are highly flexible because they can contain one task or an entire process. He does, however, provide one clear boundary by stating that entrepreneurs pay for production. Since entrepreneur and enterprise go hand in hand, the boundaries of the firm are therefore determined by that part of production paid for by a specific entrepreneur. This moves Mataja's reasoning closer to the property-rights (Alchian and Demsetz 1972; Hart and Moore 1990) and ownership-focused theories of Knight (1964) and Foss and Klein (2012) rather than those that view entrepreneurs as independent from ownership (e.g. Kirzner 1973). We now apply the integrative framework outlined above to address some open questions in the resource-based and capability literatures.

\section{Subjective Resource Value and Competitive Advantage}

This section looks more closely at the RBV in light of our framework. Although still a dominant force in strategic management research, the RBV, or specific elements of it, has been subjected to various criticisms (e.g. Priem and Butler 2001).

In a review of these critiques, Kraaijenbrink, Spender, and Groen (2010) single out three problems that lie at the heart of the RBV and that, although they have been clarified to some extent, have not been satisfactorily resolved. These problems are:

(1) An all-inclusive definition of 'resource';

(2) Indeterminate definitions of 'resource value' and 'competitive advantage' that create tautologies; and

(3) Indeterminate criteria that a resource must satisfy in order to generate a competitive advantage. 
Our framework has little to say about (1), since the concept of a higher-order good, especially in treatments of Austrian capital theory, is also rather broad (Lachmann 1978; Lewin and Baetjer 2011). However, by integrating the entrepreneur into the firm, our approach provides valuable insight into the question of resource value and its relation to competitive advantage (2), and the necessary constituents of competitive advantage (3).

\subsection{Resources and Value}

Mataja provides a clear and consistent account of the relation between value and resources. As explained above, in his theory, the general explanation of entrepreneurial profit is the successful deployment of productive resources. A core feature of the RBV is that profit is based on access to idiosyncratic resources (Barney 1991; Peteraf 1993), and profit is also an indirect outcome of capability theory (Helfat and Peteraf 2009; Teece 2007). Barney's model (1991) does not feature profit predominately-he defines his explanatory goal of Sustained Competitive Advantage (SCA) in terms of unique strategies-yet in Peteraf's (1993) definition of SCA, profit takes center stage. For her, bundles of resources differ across firms in terms of their efficiency, and this difference gives rise to rents. These rents can be interpreted as economic profits-defined as excess over opportunity costs-which in turn serve as the definition of competitive advantage (Foss and Knudsen 2003). Foss and Knudsen (2003) argue that defining competitive advantage in terms of economic profits has benefits over definitions in terms of unique strategies (Barney 1991). For example, the profit-based meaning provides easy connections to literature on organizational and industrial economics and avoids situations in which a firm is said to have a competitive advantage even if it incurs losses. Peteraf and Barney (2003), however, argue that this definition of SCA is too broad, as it not only captures the contribution of the resources deployed, but also incorporates external influences such as industry structure. This argument tries to decontextualize resource value and SCA by implying that there is an objective resource value independent from some if not all factors outside the resource itself. However, as we will argue, resources have value only because of the subjective imagination of the entrepreneurs employing them (and ultimately, the consumers who purchase the final products). This imagination is partly built on resource features and their connection to other resources, but also on more comprehensive entrepreneurial planning that includes external parameters.

The tautology critique mentioned above states that both the explanans (resources) and the explananadum (SCA) contain the concepts of value and uniqueness, leading to a situation where value is explained by value (Kraaijenbrink, 
Spender, and Groen 2010; Lockett, Thompson, and Morgenstern 2009; Priem and Butler 2001). According to Priem and Butler (2001), this is mainly due to an ambiguous treatment of value. Fortunately, our framework resolves this ambiguity. Resource value is ultimately determined by consumers and revealed by the prices they pay. Given the price of the final product, the entrepreneur is able to calculate the contribution of the individual resources. Lippman and Rumelt (2003a) correctly argue that co-specialization and dispersed ownership leading to a 'fundamental transformation' (Williamson 1985) may make this especially difficult in individual cases. However, even in general this calculation is far from trivial. Because the consumer's valuation of the final product is also unknown, entrepreneurs can struggle to ascribe a certain value to productive resources. Resource costs are incurred before the product is sold and the entrepreneur provides the important function of financing production. This requires 'anticipative judgment[s]' about future states (Mataja 1966: 149). Since resource value is derived from the future use value of the final product, the entrepreneur can only use their imagination to form an estimate, which makes resource values inherently subjective, rather than objectively given (Lachmann 1978). Only when the product is sold does it become apparent whether the entrepreneur was right and will receive a profit, or was wrong and will incur a loss. Even if the same resource is used to produce the same final product, its value remains unknown ex ante and is subject to change. This leads to the paradoxical conclusion that the real value of a resource at a specific time and place can only be known after it is deployed, when an investment is made (Foss and Klein 2012). This explains why Mataja ascribes to the entrepreneur the specific function of responsibility for production.

\subsection{Competitive Advantage}

There have been some attempts to solve the tautology problem that follow similar directions as the one proposed here. Bowmann and Ambrossini (2000), for example, introduce different types of consumer values (perceived, monetary, exchange). This solution provides a relevant level of detail but leaves the connection to resource value undefined. Closely related are Peteraf and Barney (2003), who outline resource value as the difference between perceived consumer value and the costs of the firm, but retain an objective notion of value and ex post reasoning, without an entrepreneur. Kraaijenbrink, Spender, and Groen (2010) suggest not differentiating value but rather its occurrence in time, e.g. when a resource is acquired and when it generates SCA. While the time aspect is an important step forward, they correctly point out that too restrictive a treatment can leave no room for managerial or entrepreneurial action. In a similar vein, Freiling, Gersch, and Goeke (2008) argue 
that actions based on specific resources can yield insights (e.g. customer feedback) that lead to a new evaluation of these resources. This hints at the backward imputation we suggest here; however, it also imports common problems of knowledgebased theories such as the endogenous determination of knowledge (Felin and Foss 2005) and infinite regress (Hallberg and Felin 2020; Kraaijenbring et al. 2010). Lippman and Rumelt (2003a) look at the theoretical foundations of the RBV and argue that the ambiguous notion of value and other logical inconsistencies are imported from the neoclassical treatment of economic rents and costs. While they correctly argue that resources are paid based on a subjective notion of costs, they too favor an objective approach in which resource value is attributed to superiority. A special or distinguished resource that is somehow able to reduce the costs of production can also contribute to profit as a "random" element (Mataja 1966: 162). It need not be unique, however, nor does its value need to be obvious to everyone. The "special" aspect is not in itself a source of profit (or SCA) but simply allows for an increase in its magnitude. Yet without the below-mentioned reasons for sustained profit, special resources quickly lose their ability to generate entrepreneurial profit because their cost-reducing qualities become priced. This implies their tradeability. However, resource combinations do not need to be unpriced to generate a profit (Lippman and Rumelt 2003a; Foss and Ishikawa 2007). Profit depends on the correct imagination of the future, a corresponding entrepreneurial plan, and its successful execution. While resources and capabilities play a major role in these, it is derived from entrepreneurial action. A specific, unique, or special resource may be at the core of this process, but an ordinarily priced resource can generate CA too if it is deployed according to a superior plan. This is not about the resource as such but about entrepreneurial perception of it, or to be more precise, of its attributes and services (Foss and Klein 2012; Penrose 1959).

Entrepreneurial profit and CA are therefore manifestations of value creation by successfully satisfying consumer needs. Failure to satisfy customers is manifested in the value destruction signaled by entrepreneurial loss. Profit depends on correctly aligning entrepreneurial foresight to future customer demand, making continuously accurate judgments a necessary precondition of SCA, and clarifying point (3) above. This provides detail to the general assertion by Foss et al. (2008: 88 ) that, '[m]any rent-generating resources and capabilities are developed due to consistent exercise of superior entrepreneurial judgment by managers over time,' and directly answers the request of Kraaijenbrink, Spender, and Groen (2010: 361) to develop 'a resource-based explanation of SCA that focuses on the differences in people's capacities to identify or imagine and judge the potential risks and benefits associated with the ownership of resources.'

Despite this clear single source of SCA, constraints on the adaption of production are also relevant. Competition leads to the convergence of prices for final 
products and costs of production, ultimately reducing entrepreneurial profit to zero. The economic effect of the entrepreneur is not disruption, as for Schumpeter (1934), but a kind of equilibration, similar to Kirzner (1973). There is an 'eliminating tendency' (Mataja 1966, p. 168) in entrepreneurial profits because competition decreases the prices for final products while increasing the prices for productive resources. This never-ending process, as we have noted above, is the economic baseline; however, Mataja provides different reasons why this process may be disturbed or slowed down. For example, demand shocks may not immediately be internalized by the market. Higher demand for the final product increases the prices entrepreneurs receive while the costs of production do not adapt instantaneously. Furthermore, for resources that have several different uses, a small demand surge from one industry or entrepreneur may not immediately affect resource prices at all, providing a further source of profits.

\subsection{Resource Criteria and Conditions for SCA}

More important however, are Mataja's reasons why the elimination of profits (equilibration) may be prevented for longer periods of time. Supply and demand as well as consumer preferences are constantly changing, forcing entrepreneurs and their firms to adapt. However, changing the production structure is neither trivial nor free. Transferring capital goods can be difficult and costly, and the same holds true for both specific knowledge that can only be used in specific production steps because it is tacit (Hayek 1945) and co-specialization with other resources (Baetjer and Lewin 2011; Teece 1986). Moreover, entrepreneurs only possess an incomplete picture of market conditions, especially with regard to the relative profitability of different lines of business, sales channels, and points of purchase, which means they face "true" uncertainty as they make decisions about resource deployments (Foss and Klein 2012; Knight 1964; Mataja 1966). Finally, legal barriers such as privileges, patents, and regulatory entry barriers like skill and knowledge requirements can sustain entrepreneurial profit. It is noticeable that Mataja does not emphasize inimitability beyond legal protection. Bylund (2015) argues that inimitability is impossible because every resource used in production needs to be reproduced or maintained at some point. Inimitability cannot therefore be a source of SCA, since a resource that is not reproduced will be consumed over time. Legal protection, however, allows both inimitability and reproduction. Since these are reasons that make adaption to changing environmental conditions difficult, it is generally possible that no entrepreneur is able to adapt, leaving profits at zero or causing losses. However, if one entrepreneur adjusts successfully, others cannot always easily follow, leading to sustained profits. These points describe the immobility of resources, issues of complementary, asymmetric, 
and bounded knowledge, and barriers to imitation. All are core themes of the RBV and capability theory that are especially apparent in the seminal articles by Barney (1991), Peteraf (1993), and Teece, Pisano, and Shuen (1997). Barney (1991) lists heterogeneity, immobility, value, rareness, inimitability, and nonsubstitutability as characteristics needed for a resource to provide SCA. Peteraf (1993) speaks of heterogeneity, immobility, and ex ante and ex post barriers to competition, while Teece, Pisano, and Shuen (1997) emphasize complementarity and co-specialization. These have generally been proposed as primary conditions for SCA and have sparked discussions about their logical underpinnings, i.e. their necessity and sufficiency for SCA (Foss and Knudsen 2003; Kraaijenbrink, Spender, and Groen 2010). In a review of industrial organization literature, Foss and Knudsen (2003) argue that only heterogeneity of expectations, i.e. uncertainty, and immobility through sunk cost commitments are necessary for SCA. Our framework agrees, and would see most of the factors proposed by RBV scholars as secondary: they relieve the entrepreneur for a period of time from the need to constantly adjust and make correct judgments. They nevertheless depend on at least one initial correct judgment that puts the entrepreneur in an advantageous position. The primary conditions for SCA, as discussed above, are differences in the imagination of future customer preferences and subsequent entrepreneurial action, as well as the fact that adapting existing resource and production structures is costly (sometimes prohibitively so). We summarize some critiques of the RBV and our suggested solutions in Table 1.

Table 1: Critiques of RBV and possible responses based on our framework.

Critique Our solution

RBV

Indeterminate definitions of 'resource value' and 'competitive advantage' that create tautologies.

Resource value is determined by backward imputation and imagination of the entrepreneur. Entrepreneurs imagine consumer needs and evaluate resources accordingly. This "entrepreneurial judgment" leads to CA if correct. If continuously so, then correct judgments lead to SCA.

Indeterminate criteria that a resource must There are no objective resource criteria that satisfy in order to generate a competitive advantage. constitute SCA. It is differences in the imagination about future consumer needs and the subsequent entrepreneurial action that create CA. Commonly discussed characteristics like immobility, heterogeneity, rareness, etc., are secondary, as they relieve entrepreneurs for a period of time from the need to adjust. $\mathrm{N} / \mathrm{A}$ 


\section{Capabilities and Entrepreneurial Judgment}

Capability theory also faces considerable, mostly interrelated, criticisms that still have not been completely resolved. This section investigates these criticisms using the framework presented above and shows how it tackles the following five issues:

1. Heterogeneity is stated rather than explained (Argyres et al. 2012).

2. Capabilities lack microfoundations (Abell et al. 2008; Felin, Foss, and Ployhart 2015; Felin and Foss 2005; Salvato 2003).

3. Capability theory fails at explaining the CA of organizations not grounded in routinization (Möller and McCaffrey 2021).

4. The causal relationship between dynamic and ordinary capabilities and resources is reversed (Bylund 2013).

5. Dynamic capability theory is too concerned with adaptability and neglects strategic choices (Pisano 2017).

\subsection{Heterogeneity}

Explaining differences in competitive advantage is the core explanatory goal of both the RBV and capability theory. Differences are attributed to heterogeneous endowments of resources and capabilities, making heterogeneity the hallmark of strategic management. However, heterogeneity is rarely explained bung. Jacobides and Winter (2012), for example, state that heterogeneity is an 'observable fact' and its origins can be sufficiently explained by the capability creation process. This process, however, is commonly seen as an accumulation of experiences and knowledge that always requires some pre-existing experience, leading to an infinite regress (Felin and Foss 2011; Halberg and Felin 2020).

Mataja's distinction between 'specific' and 'random' elements of profit introduces two interrelated sources of heterogeneity. First, the judgment and imagination of entrepreneurs differ, leading to different profits. As noted above, the notion of judgment is still vague. However, there have been several suggestions for how to clarify the concept, including presenting it as creativity, heuristics, and confidence in the face of uncertainty (Foss and Klein 2012), intuition and gut feeling (Foss and Klein 2015; Huang and Pearce 2015; Klein 2017), empathic accuracy (McMullen 2015) or customer need diagnosis (Godley and Casson 2015). Drawing from Mataja, we suggest also scenario planning that not only looks at understanding the customer, but also considers how needs can be met given existing knowledge, production structures, and prices, and how additional 
required resources fit in. All of these are underlying causes of heterogeneous entrepreneurial judgment.

Second, Mataja (1966: 161) discusses his 'random' elements of profit as a way to look deeper into 'individual differences in entrepreneurial income.' He argues that bargaining power, knowledge and skills, and efficiency and optimization modify profits in different ways. This provides another layer of heterogeneity and both can create effects independent from each other. Having exhausted the efficiency gains of an existing technology or production process, different imagination about how and where to direct this process leads to different profits. On the other hand, similar judgments lead to different outcomes when the efficiency of processes differs. However, both sources of heterogeneity can also be interdependent. Idiosyncratic knowledge can be a way to better understand the needs of customers and at the same time provide bargaining power to better exploit their willingness to pay.

\subsection{Microfoundations}

Each source of heterogeneity is related to microfoundations, which is unsurprising, as Mataja's approach is rooted in "methodological individualism." Based on the same reasoning, our framework argues, along with Felin et al. (2012), that there is a wide range of possible sources of heterogeneity that can be found in individuals, structures, and processes. Individuals include the entrepreneur, managers, and employees. Structures refer to existing resource combinations and organizational designs, while processes are concerned with the interactions of the former.

There has been considerable discussion of microfoundations since the first calls for them appeared (Abell et al. 2008; Felin and Foss 2005; Felin, Foss, and Ployhart 2015; Salvato 2003), and which points back to the theory's early contributions (Eisenhardt and Martin; 2000; Teece, Pisano, and Shuen 1997; Zollo and Winter 2002). This led to growing appreciation of lower-level causes in capability theory especially with regard to the entrepreneur as a person and executive management. Entrepreneurs possess a 'managerial entrepreneurial capability' (Teece 2012), or a 'cognitive managerial capability' (Helfat and Peteraf 2014), or make decisions based on habits (Zollo and Winter 2012) or cognitive frames (Gavetti 2005). These entail skills and experience along with cognition

7 This term was coined by Schumpeter $(1908,1909)$ only after Mataja had published his major work on entrepreneurship. But the general approach it describes was present in the work of Menger and his direct followers. 
and social capital (Helfat and Martin 2015) or perception and problem-solving, as well as social cognition and communication (Helfat and Peteraf 2014). There is considerable overlap here with the types of judgment we suggested above. As such, this particular stream of the capability literature may provide an opportunity to further enhance the notion of entrepreneurial judgment.

\subsection{Capabilities and Organizational Design}

Yet capability theory still falls short when it comes to including employees and considering the importance of organizational design. Several empirical studies argue that employees play a crucial role in routine and capability creation and change (e.g. Buchner and Langley 2016; D’Adderio 2014; Dittrich et al. 2016; Salvato 2009). This can occur through mindful ordinary activities (Salvato 2009), active enactment and recreation (D’Adderio 2014), or reflective talk (Buchner and Langley 2016; Dittrich et al. 2016). Salvato and Rerup (2011) therefore call for the theoretical consideration of lower-level employees, and Salvato and Vasollo (2017) for explanations of capability dynamics that include both managers and employees. While some authors have suggested that dynamic capabilities are linked to less hierarchical and entrepreneurial organizational structures (e.g. Teece 2010; Wilden et al. 2013), they have looked at the problem from a more "macro" level. Yet getting into more detail at the micro level provides a significant opportunity for further theory development (Felin, Foss, and Ployhart 2015).

In our framework this is achieved through the concept of derived judgment, which explicitly argues that although ultimate decision rights remain with the owning entrepreneur, other elements of judgment can be delegated to employees, whether alone or in groups (Foss, Foss, and Klein 2008). Hence, while perception and formation of beliefs may be delegated to one, the corresponding deployment of resources may be delegated to another. The situation becomes complex when several individuals at several levels of decision making are involved, requiring more than just cognition. Interactions may be more or less patterned, repetitive, and structured.

Unusual and novel organizational designs that deliberately defy repetition are an important blind spot of the explanatory link between capabilities based on routinization and competitive advantage (Möller and McCaffrey 2021). Such designs use self-organization and full autonomy of employees with only a minimal set of rules (Felin 2015). The high variability of team composition and characteristics of projects severely restrain the development of routines, yet such organizations are still able to create SCA (Möller and McCaffrey 2021). The sources of this SCA are not 
routine-based capabilities but the delegation of entrepreneurial judgment to employees who are allowed and required to anticipate custumer demands and deploy resources accordingly. The "specific element" of profit can explain this SCA, but capability theory cannot.

\subsection{Dynamic Capabilities}

However, Felin and Powell (2016) argue that organizational design containing a high degree of delegation, self-organization, and autonomy is especially suited for the creation of dynamic capabilities. As we argued above, there is indeed some overlap between dynamic capabilities and the framework presented here, yet the issue remains that dynamic capabilities are usually conceptualized as having only an indirect effect on profit (e.g. Helfat and Peteraf 2003; Helfat et al. 2007; Wilden et al. 2013), leaving them without use when there are no ordinary capabilities to act upon. In contrast, proposing a direct relationship between the entrepreneurial acts of creating and (re-)configuring resource combinations and profit ("specific element") helps to avoid the explanatory gap in cases that bypass the assumptions of capability theory. This does not render ordinary capabilities irrelevant, but rather changes them from original sources of profit and CA to modifiers that affect its size and sustainability: what in our framework, following Mataja, is called the "random element." It follows from this that the causal explanation of capabilities is reversed. Dynamic capabilities that correspond loosely to our notion of the "specific element" create CA while ordinary capabilities, part of our "random element," modify it. The firm then becomes a vehicle for entrepreneurs to experiment with resource combinations in pursuit of imagined capabilities (Bylund 2016). Furthermore, a core assumption of dynamic capabilities is that they enable a firm to cope with rapidly changing environments, while slow or incremental change is treated as largely stability (Teece, Pisano, and Shuen 1997). The concept of dynamic capabilities is therefore restricted to a specific external context. This a remnant of the origins of the theory, which invoked resources and capabilities to explain positive profits outside a neoclassical equilibrium and then to further accommodate changes in this equilibrium (Kraaijenbrink, Spender, and Groen 2010). In the framework presented here though, change, not stasis, is the theoretical starting point, again reversing the causality of the argument. Resources are an integral part of this understanding of production, entrepreneurship, and the market process. Moreover, our argument resides in a dynamic view of the economy in which change is nothing special; in fact, it is the norm. The framework remains the same regardless of whether environmental change is slow, fast, or non-existent. 
Furthermore, perceptions of change are inherently subjective to entrepreneurs and not objective or obvious ex ante: while some entrepreneurs may follow every hype and see disruptive change around every corner, others may regard the same situation as far more stable.

\subsection{Flexibility versus Strategy}

Finally, the theoretical discussion of making the resource- and capability views dynamic is to a large extent concerned with the general flexibility of firms (Peteraf, DiStefano, and Verona 2013; Pisano 2017). This neglects other important strategic aspects though. Mataja argues that one reason profits can be sustained is because adaptation is costly since resources cannot be combined and separated for free. This may be due to transaction costs related to the definition and enforcement of property rights or associated with learning (Foss and Foss 2008). It implies that resource deployments increase the costs of future deployment and reconfiguration. Therefore, a decision to reconfigure the resource base can deliberately reduce future flexibility. This can, for example, be the case when market entry is delayed to gather additional knowledge (O’Brien et al. 2003). In turn, exercising superior judgment can mean not adapting, in order to stay flexible. This suggests an important trade-off that has rarely been considered. Exceptions include Collan et al. (2014) who propose strategic real options as a supplement to dynamic capabilities and Pisano (2017), who argues that the literature on dynamic capabilities is too concerned with making firms adaptable, while neglecting the strategic decisions and trade-offs that are actually involved when resources and capabilities are transformed. Such decisions include making resource commitments that reduce adaptability but secure competitive advantage, choosing between capability specialization and creation, or between the creation of capabilities that have a broad range of uses and those that are highly specific. While some of these ideas have been around since Teece, Pisano, and Shuen (1997) in the concepts of 'positions' and 'paths,' they are seldom discussed as crucial aspects of dynamic capabilities. This may be due to the heavy reliance on evolutionary thinking and a deterministic concept of path-dependency that leaves little room for active decision making (Felin and Foss 2011). However, the costs associated with changing an existing resource configuration do not necessarily lead down a deterministic path. Costs influence the economic viability of strategic options, but there is no automatic choice between them. Costly reconfigurations should be carefully considered. They can be the right way forward, for example, when inadequate resource combinations that cause rigidities (Leonard-Barton 1992) have to be dissolved or strategic flexibility should be increased. Furthermore, adaption is no guarantee of success. As noted above, judgments can be wrong, 
causing losses for the entrepreneur. Polaroid, for example, famously failed to survive despite changes to their resource structure because of incorrect anticipations of customer preferences (Tripsas and Gavetti 2000). Our arguments regarding capabilities are summarized in Table 2.

Table 2: Critiques of capabilities and possible solutions based on our framework.

\begin{tabular}{|c|c|}
\hline Critique & Our solution \\
\hline \multicolumn{2}{|l|}{ Capabilities } \\
\hline Heterogeneity is stated rather than explained. & $\begin{array}{l}\text { Heterogeneity arises out of (a) different judg- } \\
\text { ments of entrepreneurs and (b) different abili- } \\
\text { ties, skills, and knowledge of entrepreneurs. }\end{array}$ \\
\hline Capabilities lack microfoundations. & $\begin{array}{l}\text { Microfoundations can be found in individuals } \\
\text { (e.g. entrepreneurs, managers, employees), } \\
\text { structures (resource combinations, organiza- } \\
\text { tional designs), and processes (interaction of } \\
\text { the former). }\end{array}$ \\
\hline $\begin{array}{l}\text { Capability theory fails at explaining the CA of } \\
\text { organizations not grounded in routinization. }\end{array}$ & $\begin{array}{l}\text { CA is explained by correct judgment. If dele- } \\
\text { gated to employees, their judgment can create } \\
\text { SCA even in non-routine environments. }\end{array}$ \\
\hline $\begin{array}{l}\text { The causal relationship between dynamic and } \\
\text { ordinary capabilities and resources is reversed. }\end{array}$ & $\begin{array}{l}\text { The "specific" element of profit is the correct } \\
\text { anticipation of future customer needs and the } \\
\text { corresponding acquisition, creation, and } \\
\text { deployment of resources. This includes their } \\
\text { adaption when the imagination of the future has } \\
\text { changed. "Random" elements including bar- } \\
\text { gaining power, knowledge, skills, routines, and } \\
\text { processes only affect the size of profit; they are } \\
\text { not its original source. }\end{array}$ \\
\hline $\begin{array}{l}\text { Dynamic capability theory is too concerned with } \\
\text { adaptability and neglects strategic choices. }\end{array}$ & $\begin{array}{l}\text { Exercising judgment does not always imply } \\
\text { adaptation but can also mean preserving the } \\
\text { status quo. Furthermore, deploying resources } \\
\text { can lead to reduced flexibility. Therefore } \\
\text { adaptability comes at a cost and needs to be } \\
\text { carefully considered. }\end{array}$ \\
\hline
\end{tabular}

\section{Discussion and Conclusions}

We have shown how our framework, which draws on the early Austrian perspective on entrepreneurship and the firm developed by Victor Mataja, helps to more strongly connect economics, entrepreneurship, and strategic management literature, and to 
expand the latter. In particular, Mataja's theory of entrepreneurship and production provides important core elements of our framework that integrate additional economic concepts into the judgment-based approach to entrepreneurship, the resource-based view of the firm, and capabilities theory, and thereby paves the way for a more expansive view of strategic decision-making. More broadly, this paper contributes to an ongoing effort to "rehabilitate" valuable contributions to entrepreneurship studies that have been overlooked or forgotten, but that can also provide substantial value to contemporary work. Many such insights can be found in the work of Austrian economists, past and present (McCaffrey 2018).

In particular, we apply our framework to open questions in the resource-based and capability views and show how they can be answered. For the RBV, by treating the entrepreneur and the firm as a union and emphasizing Menger's theory of goods, we were able to show that entrepreneurial judgment, a subjective notion of value, and the time-related idea of backward imputation of value can provide more robust definitions of resource value and competitive advantage that avoid tautologies. Based on this, we identified good judgment as the main cause of CA. Regarding the capability view, we argued that individual judgments and the distinction between specific and random elements of profit provide interrelated sources of the heterogeneity of firms. Looking in more detail into the sources of profit, we argue that the causality between ordinary and dynamic capabilities should be reversed.

Using Mataja's (1966) concept of scenario analysis to determine future customer preferences and current resource values, we provide an additional, more practicerelated microfoundation of judgment. Furthermore, secondary determinants of profit and CA like superior knowledge and individual traits offer other microfoundations for judgment. This suggests that considering the literature on individual entrepreneurial characteristics may be worthwhile in advancing the JBA. The same holds for recent contributions to the microfoundations of managerial dynamic capabilities that emphasize perception and decision-making just as the JBA does, but further introduce social cognition and communication (Helfat and Peteraf 2014). However, this focus on managerial microfoundations is challenged by findings that highlight the contributions of lower-level employees to capability development (e.g. Buchner and Langley 2016; Dittrich et al. 2016; Salvato 2009). The JBA concept of derived judgment can provide a useful framework for shedding light on this discrepancy (Foss, Foss, and Klein 2007).

Our conceptualization of entrepreneurship as deploying resources based on imagining an uncertain future equally includes exploration and exploitation as integral activities. This is apparent in our discussion of the specific as well as the random elements of profit. The former require imagination about consumer preferences and resource characteristics along with the ability to deploy resources to create CA. The 
latter contain more explorative elements like superior market knowledge and customer understanding and more exploitative ones like the more efficient use of resources. Thus, it provides a conceptual basis for moving entrepreneurship research from a predominantly explorative (Shane and Venkatamaran 2000) into a more ambidextrous direction (Freiling and Schelhowe 2014). Moreover, our integrative view of entrepreneurship overlaps with ideas from other research on exploratory entrepreneurial activities (opportunity seeking) and exploitative strategic activities (advantage seeking) in strategic entrepreneurship (Ireland, Hitt, and Sirmon 2003; Ketchen, Ireland, and Snow 2007). However, like dynamic capabilities, strategic entrepreneurship emphasizes adaptation and innovation (Hitt et al. 2011; Kuratko 2010). Our argument that non-change can be a viable strategy for creating and sustaining CA is also valuable here.

Furthermore, when entrepreneurship can be undertaken by a variety of individuals, it makes possible a fine-grained analysis of specialized decision-rights that may be exploratory or exploitative. This comprehensive theory thus provides a new angle from which to discuss ambidexterity in organizations and to explore questions like: Which parts of the entrepreneurial function are delegated, and why? And how can they be coordinated to ensure the efficient execution of the overall entrepreneurial function? It also contributes to core issues of strategic entrepreneurship (Ireland, Hitt, and Sirmon 2003) and the entrepreneurial orientation of firms (Freiling and Schelhowe 2014), while emphasizing the importance of organizational structure and design for these problems (Foss, Foss, and Klein 2007; Wilden et al. 2013).

Nevertheless, despite the value of this more integrated framework, there are also potential drawbacks. The most important is the difficulty of applying historical texts, especially in translation, to recent debates. Older works often predate the introduction of modern concepts, or use those concepts more loosely or ambiguously than contemporary research. There is therefore a danger of anachronism and "rational reconstruction" (Blaug 1990, 2001). Great care is therefore required when integrating concepts and theories from different eras. And although we are confident that our translations and interpretations are accurate and reasonable, we do not rule out alternate views.

\section{References}

Abell, P., T. Fellin, and N. Foss. 2008. "Building Micro-foundations for the Routines, Capabilities, and Performance Links." Managerial and Decision Economics 29 (6): 489-502.

Alchian, A. A., and H. Demsetz. 1972. "Production, Information Costs and Economic Organization." The American Economic Review 62 (5): 777-95. 
Alvarez, S. A., and Z. L. W. Busenit. 2001. "The Entrepreneurship of Resource-based Theory.” Journal of Management 27 (6): 755-75.

Amit, R., and P. J. H. Schoemaker. 1993. "Strategic Assets and Organizational Rent." Strategic Management Journal 14 (1): 33-46.

Argyres, N. S., and U. Zenger. 2012. "Capabilities, Transaction Costs, and Firm Boundaries." Organization Science 23 (6): 1523-783.

Argyres, N. 2011. "Using Organizational Economics to Study Organizational Capability Development and Strategy." Organization Science 22 (5): 1138-43.

Argyres, N. S., F. Teppo, N. J. Foss, and T. Zenger. 2012. "Organizational Economics of Heterogeneity and Capability." Organization Science 23 (5): 1213-26.

Baetjer, H., and P. Lewin. 2011. "The Capital-Based View of the Firm." Review of Austrian Economics 24 (4): 335-54.

Barney, J. B. 1986. "Strategic Factor Markets: Expectations, Luck, and Business Strategy." Management Science 32 (10): 1231-41.

Barney, J. B. 1991. “Firm Resources and Sustained Competitive Advantage." Journal of Management 17(1): 99-120.

Barney, J. B. 2001. "Is the Resource-Based "View" a Useful Perspective for Strategic Management Research? Yes." Academy of Management Review 26 (1): 41-56.

Baumol, W. J. 1968. "Entrepreneurship in Economic Theory." The American Economic Review 58 (2): 64-71.

Baumol, W. J. 1993. "Formal Entrepreneurship Theory in Economics: Existence and Bounds. Journal of Business Venturing 8 (3): 197-210.

Blaug, M. 1990. “On the Historiography of Economics.” Journal of the History of Economic Thought 12 (1): $27-37$.

Blaug, M. 2001. “No History of Ideas, Please, We're Economists." The Journal of Economic Perspectives 15 (1): 145-64.

Böhm-Bawerk, E-V. 1959. Positive Theory of Capital. Trans. G. D. Huncke, and H. F. Sennholz. South Holland: Libertarian Press.

Böhm-Bawerk, E-V. 1962. “The Austrian Economists.” In Shorter Classics of Böhm-Bawerk. South Holland: Libertarian Press: 1-24.

Bowman, C., and V. Ambrosini. 2000. "Value Creation versus Value Capture: Towards a Coherent Definition of Value in Strategy." British Journal of Management 11 (1): 1-15.

Buchner, S., and A. Langley. 2016. "The Interplay of Reflective and Experimental Spaces in Interrupting and Reorienting Routine Dynamics.” Organization Science 27 (3): 594-613.

Bylund, P. L. 2013. The Firm: Heterogenizing Heterogeneous Resources. Working Paper. Also available at https://papers.ssrn.com/sol3/papers.cfm?abstract_id=2308076\&download=yes.

Bylund, P. L. 2015. "Explaining Firm Emergence: Specialization, Transaction Costs, and the Integration Process." Managerial and Decision Economics 36 (4): 221-38.

Bylund, P. L. 2016. The Problem of Production. New York: Routledge.

Collan, M., J. Freiling, K. Kyläheiko, and E. Roemer. 2014. "Entrepreneurship and the Art of Tackling Technological Crises: A Strategic Real Options Framework." International Journal of Technology Intelligence and Planning 10 (2): 166-85.

Connell, C. M. 2007. "Fritz Machlup's Methodology and the Theory of the Growth of the Firm." Quarterly Journal of Austrian Economics 10 (4): 300-12.

Conner, K. R., and C. K. Prahalad. 1996. "A Resource-Based Theory of the Firm: Knowledge versus Opportunism.” Organization Science 7 (5): 477-501. 
D’Adderio, L. 2014. “The Replication Dilemma Unravelled: How Organizations Enact Multiple Goals in Routine Transfer." Organization Science 25 (5): 1325-50.

Demsetz, H. 1988. "The Theory of the Firm Revisited." Journal of Law, Economics, and Organization 4 (1): 141-61.

Dittrich, K., S. Guérard, and D. Seidl. 2016. "Talking about Routines: The Role of Reflective Talk in Routine Change.” Organization Science 27 (3): 678-97.

Eisenhardt, K. M., and J. A. Martin. 2000. "Dynamic Capabilities: What Are They?" Strategic Management Journal 21 (10-11): 1105-21.

Felin, T., and N. J. Foss. 2005. "Strategic Organization: A Field in Search of Micro-foundations." Strategic Organization 3 (4): 441-55.

Felin, T., and N. J. Foss. 2011. "The Endogenous Origins of Experience, Routines, and Organizational Capabilities: The Poverty of Stimulus." Journal of Institutional Economics 7 (2): 231-56.

Felin, T., N. J. Foss, K. H. Heimeriks, and T. L. Madsen. 2012. "Microfoundations of Routines and Capabilities: Individuals, Processes, and Structure.” Journal of Management Studies 48 (8): 1351-74.

Felin, T., N. J. Foss, and R. E. Ployhart. 2015. "The Microfoundations Movement in Strategy and Organization Theory." The Academy of Management Annals 9 (1): 575-632.

Felin, T., and T. C. Powell. 2016. “Designing Organizations for Dynamic Capabilities.” California Management Review 58 (4): 78-96.

Foss, K., and N. J. Foss. 2008. "Understanding Opportunity Discovery and Sustainable Advantage: The Role of Transaction Costs and Property Rights.” Strategic Entrepreneurship Journal 2 (3): 191-207.

Foss, N. J., and I. Ishikawa. 2007. "Towards a Dynamic Resource-based View: Insights from Austrian Capital and Entrepreneurship Theory.” Organization Studies 28 (5): 749-72.

Foss, N. J., and P. G. Klein. 2005. "Entrepreneurship and the Theory of the Firm: Any Gains from Trade?" In Handbook of Entrepreneurship Research: Disciplinary Perspectives, edited by R. Agarwal, S. A. Alvarez, and O. Sorenson, 55-80. New York: Springer.

Foss, N. J., and P. G. Klein. 2012. Organizing Entrepreneurial Judgment: A New Approach to the Firm. Cambridge: Cambridge University Press.

Foss, N. J., and P. G. Klein. 2015. "Introduction to a Forum on the Judgment-Based Approach to Entrepreneurship: Accomplishments, Challenges, New Directions." Journal of Institutional Economics 11 (3): 585-99.

Foss, N. J., and T. Knudsen. 2003. "The Resource-based Tangle: Towards a Sustainable Explanation of Competitive Advantage." Managerial and Decision Economics 24 (4): 291-307.

Foss, K., N. J. Foss, and P. G. Klein. 2007. "Original and Derived Judgment: An Entrepreneurial Theory of Economic Organization.” Organization Studies 28 (12): 1893-912.

Foss, N. J., P. G. Klein, Y. K. Kor, and J. T. Mahoney. 2008. "Entrepreneurship, Subjectivism, and the Resource-Based View: Toward a New Synthesis." Strategic Entrepreneurship Journal 2 (1): 73-94.

Foss, N. J., P. G. Klein, and M. McCaffrey. 2019. Austrian Perspectives on Entrepreneurship, Strategy, and Organization. Cambridge: Cambridge University Press.

Freiling, J., and C. L. Schelhowe. 2014. "The Impact of Entrepreneurial Orientation on the Performance of Internationalization.” Journal of Entrepreneurship, Management and Innovation 10 (4): 169-99. 
Freiling, J., M. Gersch, and C. Goeke. 2008. "On the Path towards a Competence-based Theory of the Firm.” Organization Science 29 (8/9): 1143-64.

Gavetti, G. 2005. "Cognition and Hierarchy: Rethinking the Microfoundations of Capabilities' Development." Organization Science 16 (6): 599-617.

Godley, A. C., and M. C. Casson. 2015. “'Doctor, Doctor ...' Entrepreneurial Diagnosis and Market Making." Journal of Institutional Economics 11 (3): 601-21.

Grechenig, K., and M. Gelter. 2008. "The Transatlantic Divergence in Legal Thought: American Law and Economics vs. German Doctrinalism." Hastings International and Comparative Law Review 31 (1): 295-360.

Grossman, S. J., and O. D. Hart. 1986. "The Costs and Benefits of Ownership: A Theory of Vertical and Lateral Integration." Journal of Political Economy 94 (4): 691-719.

Hallberg, N. J., and T. Felin. 2020. "Untangling Infinite Regress and the Origins of Capability." Journal of Management Inquiry 29 (1): 17-32.

Hart, O., and J. Moore. 1990. "Property Rights and the Nature of the Firm." Journal of Political Economy 98 (6): 1119-58.

Helfat, C. E., and M. B. Lieberman. 2002. "The Birth of Capabilities: Market Entry and the Importance of Pre-history." Industrial and Corporate Change 11 (4): 725-60.

Helfat, C. E., and J. A. Martin. 2015. "Dynamic Managerial Capabilities: Review and Assessment of Managerial Impact on Strategic Change.” Journal of Management 41 (5): 1281-312.

Helfat, C. E., and M. A. Peteraf. 2003. "The Dynamic Resource-based View: Capability Lifecycles." Strategic Management Journal 24 (10): 997-1010.

Helfat, C. E., and M. A. Peteraf. 2009. "Understanding Dynamic Capabilities: Progress along a Developmental Path.” Strategic Organization 7 (1): 91-102.

Helfat, C. E., and M. A. Peteraf. 2014. "Managerial Cognitive Capability and the Microfoundations of Dynamic Capabilities." Strategic Management Journal 36 (6): 831-50.

Helfat, C. E., and S. G. Winter. 2011. "Untangling Dynamic and Operational Capabilities: Strategy for the (N)ever-Changing World." Strategic Management Journal 32 (11): 1243-50.

Helfat, C., S. Finkelstein, W. Mitchell, M. Peteraf, H. Singh, D. Teece, and S. Winter. 2007. Dynamic Capabilities: Understanding Strategic Change in Organizations. Malden: Blackwell.

Hitt, M. A., D. R. Ireland, D. G. Sirmon, and C. A. Trahms. 2011. "Strategic Entrepreneurship: Creating Value for Individuals, Organizations and Society." Academy of Management Perspectives 25 (2): 57-75.

Holmström, B., and J. Roberts. 1998. "The Boundaries of the Firm Revisited." The Journal of Economic Perspectives 121 (4): 73-94.

Huang, L., and J. L. Pearce. 2015. "Managing the Unknowable: The Effectiveness of Early-Stage Investor Gut Feel in Entrepreneurial Investment Decisions." Administrative Science Quarterly 60 (4): 634-70.

Hülsmann, G. 2007. Mises: The Last Knight of Liberalism. Auburn: Ludwig von Mises Institute.

Ireland, R. D., M. A. Hitt, and D. G. Sirmon. 2003. "A Model of Strategic Entrepreneurship: The Construct and its Dimensions." Journal of Management 29 (6): 963-89.

Ireland, R. D., J. G. Covin, and D. F. Kuratko. 2009. “Conceptualizing Corporate Entrepreneurship Strategy." Entrepreneurship: Theory and Practice 33 (1): 19-49.

Jacobides, M. G., and S. G. Winter. 2012. "Capabilities: Structure, Agency, and Evolution.” Organization Science 23 (5): 1365-81.

Jacobson, R. 1992. "The “Austrian” School of Strategy.” Academy of Management Review 17 (4): 782-807. 
Jensen, M. C., and W. H. Meckling. 1976. "Theory of the Firm: Managerial Behavior, Agency Costs and Ownership Structure." Journal of Financial Economics 3 (4): 305-60.

Ketchen, D. J., R. D. Ireland, and C. C. Snow. 2007. "Strategic Entrepreneurship, Collaborative Innovation, and Wealth Creation.” Strategic Entrepreneurship Journal 1 (3-4): 371-85.

Kirzner, I. M. 1966. An Essay on Capital. New York: August M. Kelley.

Kirzner, I. M. 1973. Competition and Entrepreneurship. Chicago: University of Chicago Press.

Kirzner, I. M. 1978. “The Entrepreneurial Role in Menger’s System.” Atlantic Economic Journal 6 (3): 31-45.

Kirzner, I. M. 1997. “Entrepreneurial Discovery and the Competitive Market Process: An Austrian Approach." Journal of Economic Literature 35 (1): 60-85.

Klein, P. G. 2017. “My Contributions to Entrepreneurship Theory.” In The Routledge Companion to the Makers of Modern Entrepreneurship, edited by D. B. Audretsch, and E. E. Lehmann, 146-53. New York: Routledge.

Kleinwächter, F. 1884. "Besprechung von: Mataja, Viktor: Der Unternehmergewinn. Wien 1884.-Groß, Gustav: Die Lehre vom Unternehmergewinn. Leipzig 1884.-Schroeder, Eduard August: Des Unternehmen und der Unternehmergewinn vom historischen, theoretischen und praktischen Standpunkte, Jahrbuch für Gesetzgebung." Verwaltung und Volkswirtschaft im Deutschen Reich 8: 1277-82.

Knight, F. H. 1964. Risk, Uncertainty and Profit. New York: August M. Kelley.

Kogut, B., and U. Zander. 1992. "Knowledge of the Firm, Combinative Capabilities, and the Replication of Technology." Organization Science 3 (3): 383-97.

Kraaijenbrink, J., J.-C. Spender, and A. J. Groen. 2010. "The Resource-based View: A Review and Assessment of its Critiques.” Journal of Management 36 (1): 349-72.

Kuratko, D. F. 2010. “Corporate Entrepreneurship: An Introduction and Research Review.” In Handbook of Entrepreneurship Research: An Interdisciplinary Survey and Introduction, edited by Z. J. Acs, and D. B. Audretsch, 129-63. New York: Springer, https://doi.org/10. 1007/978-1-4419-1191-9_6.

Lachmann, L. M. 1978. Capital and Its Structure. Kansas City: Sheed Andrews and McMeel.

Langlois, R. N., and N. J. Foss. 1999. "Capabilities and Governance: The Rebirth of Production in the Theory of Economic Organization.” Kyklos 52 (2): 201-18.

Leonard-Barton, D. 1992. "Core Capabilities and Core Rigidities: A Paradox in Managing New Product Development.” Strategic Management Journal 13 (S1): 111-25.

Lewin, P., and H. Baetjer. 2011. "The Capital-based View of the Firm." The Review of Austrian Economics 24 (4): 335-54.

Lewin, P., and N. Cachanosky. 2019. "Entrepreneurship in a Theory of Capital and FinanceIllustrating the Use of Subjective Quantification.” Managerial and Decision Economics 41 (5): 735-43.

Lippman,S. A., and R. P. Rumelt. 2003a. "The Payments Perspective: Microfoundations of Resource Analysis.” Strategic Management Journal 24 (10): 903-27.

Lippman,S. A., and R. P. Rumelt. 2003b. “A Bargaining Perspective on Resource Advantage.” Strategic Management Journal 24 (11): 1069-86.

Loasby, B. J. 2002. “Explaining Firms.” In Entrepreneurship and the Firm: Austrian Perspectives on Economic Organization, edited by N. J. Foss, and P. G. Klein, 11-23. Cheltenham.

Loasby, B. J. 2007. "A Cognitive Perspective on Entrepreneurship and the Firm.” Journal of Management Studies 44 (7): 1078-106.

Lockett, A. 2005. “Edith Penrose's Legacy to the Resource-Based View.” Managerial and Decision Economics 26 (2): 83-98. 
Lockett, A., S. Thompson, and U. Morgenstern, 2009. "The Development of the Resource-based View of the Firm: A Critical Appraisal." International Journal of Management Reviews 11 (1): 9-28.

Mangold, H. 1855. Die Lehre vom Unternehmergewinn: Ein Beitrag zur Volkswirthschaftslehre. Leipzig: B.G. Teubner.

Martin, D. T. 1979. “Alternative Views of Mengerian Entrepreneurship.” History of Political Economy 11 (2): 271-85.

Mataja, V. 1888. Das Recht des Schadensersatzes vom Standpunkte der Nationalökonomie. Leipzig: Dunker and Humblot.

Mataja, V. 1916. Die Reklame: Eine Untersuchung über Ankündigungswesen und Werbetätigkeit im Geschäftsleben, 2nd. ed. München: Dunker and Humblot.

Mataja, V. (1884)1966. Der Unternehmergewinn: Ein Beitrag zur Lehre von Gütervertheilung der Volkswirtschaft. Osnabrück: Otto Zeller.

McCaffrey, M. 2016. “Good Judgment, Good Luck: Frank Fetter's Neglected Theory of Entrepreneurship." Review of Political Economy 28 (4): 504-22.

McCaffrey, M. 2018. "Extending the Economic Foundations of Entrepreneurship Research.” European Management Review 15 (2): 191-9.

McMullen, J. S. 2015. "Entrepreneurial Judgment as Emphatic Accuracy: A Sequential Decision-making Approach to Entrepreneurial Action." Journal of Institutional Economics 11 (3): 651-81.

Menger, C. 1871. Grundsätze der Volkswirtschaftslehre. Wien: Wilhelm Braumüller.

Mises, L-V. (1949)1998. Human Action: A Treatise on Economics, Scholar's ed. Auburn: Ludwig von Mises Institute.

Möller, U. and M. McCaffrey. 2021. “Levels without Bosses? Entrepreneurship and Valve's Organizational Design." In The Invisible Hand in Virtual Worlds: The Economic Order of Video Games, edited by M. McCaffrey. Cambridge: Cambridge University Press.

Nagano, H. 2020. "The Impact of Knowledge Diversity: Integrating Two Economic Perspectives through the Dynamic Capability Approach.” Managerial and Decision Economics 41 (6): 1057-70.

O’Brien, J. P., T. B. Foltay, and D. R. Johnsonz. 2003. “A Real Options Perspective on Entrepreneurial Entry in the Face of Uncertainty.” Managerial and Decision Economics 24 (8): 515-33.

Olbrich, M., D. J. Rapp, and F. Follert. 2020. "Eugen Schmalenbach, Austrian Economics, and German Business Economics.” The Review of Austrian Economics, https://doi.org/10.1007/ s11138-020-00520-x.

Packard, M. D., B. B. Clark, and P. G. Klein. 2017. "Uncertainty Types and Transitions in the Entrepreneurial Process.” Organization Science 28 (5): 840-56.

Penrose, E. T. 1959. The Theory of the Growth of the Firm. Oxford: Blackwell.

Peteraf, M. A. 1993. "The Cornerstones of Competitive Advantage: A Resource-based View." Strategic Management Journal 14 (3): 179-91.

Peteraf, M. A., and J. B. Barney. 2003. “Unraveling the Resource-based Tangle.” Managerial and Decision Economics 24 (4): 309-23.

Peteraf, M. A., G. DiStefano, and G. Verona. 2013. "The Elephant in the Room of Dynamic Capabilities: Bringing Two Diverging Conversation Together.” Strategic Management Journal 34 (12): 1389-410.

Pisano, G. 2017. "Towards a Prescriptive Theory of Dynamic Capabilities: Connecting Strategic Choice, Learning, and Competition.” Industrial and Corporate Change 265: 747-62. 
Pitelis, C., and J. Runde. 2017. "Capabilities, Resources, Learning and Innovation: A Blueprint for a Post-classical Economics and Public Policy." Cambridge Journal of Economics 41 (3): 679-91.

Priem, R. L., and J. E. Butler. 2001. "Is the Resource-based "View" a Useful Perspective for Strategic Management Research?” Academy of Management Review 26 (1): 22-40.

Salerno, J. T. 2008. "The Entrepreneur: Real and Imagined." Quarterly Journal of Austrian Economics 11 (3-4): 188-207.

Salvato, C. 2003. "The Role of Micro-Strategies in the Engineering of Firm Evolution." Journal of Management Studies 40 (1): 83-108.

Salvato, C. 2009. "Capabilities Unveiled: The Role of Ordinary Activities in the Evolution of Product Development Processes.” Organization Science 20 (2): 384-409.

Salvato, C., and C. Rerup 2011. "Beyond Collective Entities: Multilevel Research on Organizational Capabilities.” Journal of Management 37 (2): 486-90.

Salvato, C., and R. Vassolo. 2017. "The Sources of Dynamism in Dynamic Capabilities." Strategic Management Journal 39 (6): 1728-52.

Schumpeter, J. A. 1908. Das Wesen und der Hauptinhalt der theoretischen Nationalökonomie. Leipzig: Duncker and Humbolt.

Schumpeter, J. A., 1909. “On the Concept of Social Value." Quarterly Journal of Economics 23 (2): 213-32.

Schumpeter, J. A. 1934. Theory of Economic Development. Cambridge, MA: Harvard University Press.

Schumpeter, J. A. 1954. History of Economic Analysis. London: Allen \& Unwin.

Schumpeter, J. A. 1983. The Theory of Economic Development: An Inquiry into Profits, Capital, Credit, Interest, and the Business Cycle. New Brunswick/London: Transaction Publishers.

Shane, S., and S. Venkatamaran. 2000. "The Promise of Entrepreneurship as a Field of Research." Academy of Management Review 25 (1): 217-26.

Teece, D. J. 1986. "Profiting from Technological Innovation: Implications for Integration, Collaboration, Licensing and Public Policy.” Research Policy 15 (6): 285-305.

Teece, D. J. 2007. "Explicating Dynamic Capabilities: The Nature and Microfoundations of (Sustainable) Enterprise Performance.” Strategic Management Journal 28 (13): 1319-50.

Teece, D. J. 2010. “Business Models, Business Strategy, and Innovation.” Long Range Planning 43 (2-3): 172-94.

Teece, D. J. 2012. “Dynamic Capabilities: Routines versus Entrepreneurial Action.” Journal of Management Studies 49 (8): 1395-401.

Teece, D. J. 2014. “The Foundations of Enterprise Performance: Dynamic and Ordinary Capabilities in an (Economic) Theory of Firms." Academy of Management Perspectives 28 (4): 328-52.

Teece, D. J., G. Pisano, and A. Shuen. 1997. "Dynamic Capabilities and Strategic Management." Strategic Management Journal 18 (7): 509-33.

Tripsas, M., and G. Gavetti. 2000. "Capabilities, Cognition and Inertia: Evidence from Digital Imaging." Strategic Management Journal, 21 (10/11): 1147-61.

von Hayek, F. A. 1945. "The Use of Knowledge in Society." The American Economic Review 35 (4): 519-30.

Wernerfelt, B. 1984. “A Resource-Based View of the Firm.” Strategic Management Journal 5 (2): 272-80.

Wilden, R., S. P. Gudergan, B. B. Nielson, and I. Lings. 2013. "Dynamic Capabilities and Performance: Strategy, Structure and Environment.” Long Range Planning 46 (1-2): 72-96. Williamson, 0. 1985. The Economic Institutions of Capitalism. New York: Free Press. 
Williamson, 0. 1991. "Strategizing, Economizing, and Economic Organization." Strategic Management Journal 12 (2): 75-94.

Williamson, 0. 1993. “Opportunism and its Critics." Managerial and Decision Economics 14 (2): 97-107.

Williamson, 0. 1999. "Strategy Research: Governance and Competence Perspectives." Strategic Management Journal 20 (12): 1087-108.

Winter, S. G. 1988. "On Coase, Competence, and the Corporation." Journal of Law, Economics, and Organization 4 (1): 163-80.

Winter, S. G. 2003. “Understanding Dynamic Capabilities.” Strategic Management Journal 24 (10): 991-5.

Zollo, M., and S. G. Winter. 2002. "Deliberate Learning and the Evolution of Dynamic Capabilities." Organization Science 13 (3): 339-51. 